\title{
The effect of fire on soil oribatid mites (Acari: Oribatida) in a South African grassland*
}

\author{
ELIZABETH A. HUGO-COETZEE ${ }^{1} \&$ NICO L. AVENANT ${ }^{1,2}$ \\ 'National Museum, PO Box 266, Bloemfontein, 9301, South Africa; \\ E-mail:Lhugo@nasmus.co.za \\ ${ }^{2}$ Centre for Environmental Management, University of the Free State, PO Box 339, Bloemfontein, South Africa \\ * In: Moraes, G.J. de \& Proctor, H. (eds) Acarology XIII: Proceedings of the International Congress. \\ Zoosymposia, 6, 1-304.
}

\begin{abstract}
Fire is a natural disturbance factor in southern African grasslands, and has become an important management tool for conservation of these habitats. Information on the impact of fire on any aspect of biodiversity will assist land managers to make more informed decisions on a fire regime that will conserve biodiversity in these grasslands. This is the first study to examine the responses of mite assemblages to fire disturbance in South African grasslands. The study was conducted in the Erfenis Dam Nature Reserve in central South Africa. An area of the Reserve was burned with a fast, hot fire while another area was left unburned as a control. Soil oribatid mites were collected over a period of one year from the burned and control areas. Oribatid assemblages exhibited seasonal patterns, with species richness and abundance slightly higher in early and late autumn and early spring. Four months after fire, there was no residual effect of fire on total abundance and species richness. However, species composition and the seasonal relative abundances of particular species, e.g. Multioppia wilsoni Aoki, 1964, Scheloribates confusia Coetzer, 1968 and Anellozetes auriculatus (Mahunka, 1984), differed between burned and control plots, demonstrating how targeted species can be investigated as indicators of post-fire recovery.
\end{abstract}

Key words: Soil arthropods, Acariformes, burning effect, conservation, indicators.

\section{Introduction}

The Grassland Biome constitutes $28 \%$ of the vegetation of South Africa, Lesotho and Swaziland (Rouget et al., 2006). It is also the most threatened biome in South Africa (Mucina et al., 2006). Only $2.2 \%$ of grassland vegetation is currently protected in parks and reserves, ca. $35 \%$ has been lost through habitat transformation and degradation, and the rest is under threat from agricultural activities (Mucina et al., 2006).

Fire is important for the conservation and management of grasslands (Swanepoel, 1981; Parr et al., 2004; Mucina et al., 2006), with the frequency, seasonality and intensity of fires being fundamental attributes determining its effects on biota (Mucina et al., 2006). Fire removes litter and promotes new nutritious growth of grasses, which results in improved feeding conditions for mammalian grazers and other herbivores including arthropods (Lubin \& Crouch, 2003; Barratt et al., 2006). Burning also prevents the incursion of woody plants (Lubin \& Crouch, 2003). Fire exclusion studies in southern Africa have indicated that in the absence of fire there was a successional trend towards shrub- or forest- vegetation (Mucina et al., 2006).

The optimal burning frequency in grasslands in South Africa differs according to the rate of litter accumulation, which in turn is largely determined by the annual rainfall (Manry \& Knight, 1986). In general, managed grasslands in South Africa are control-burned every one to four years in late winter, from July to September (Mucina et al., 2006). Fire frequency is mainly responsible for the current distribution of terrestrial plant communities in South Africa (Manry \& Knight, 1986) but less is known about its effects on faunal diversity. In a study on African savanna ants, 
burning and the frequency of burning did not have a significant effect on species richness and abundance although the ant species composition differed between burned and control plots (Parr et al., 2004). Fire also impacts small mammal community structure as it changes with succession (Ferreira \& Van Aarde, 2000; Avenant, 2005), and past fire frequency is expected to have contributed towards shaping the current small mammal species assemblages in the Southern African grasslands (Swanepoel, 1981). More information on the impact of fire on biodiversity is required so that land managers can make more informed decisions on a fire regime which will conserve biodiversity in grasslands.

Soil oribatid mites (in the traditional sense, excluding Astigmata, Krantz \& Walter, 2009) are an integral part of most grassland ecosystems (Seastedt, 1984a; Yeates \& Lee, 1997), where they are numerically abundant and play important roles in decomposition and mineralization of dead plant material, nutrient cycling, and in maintaining soil structure. Several studies have examined the effects of existing management practices on soil microarthropods, e.g. mulching and mowing of mountain meadows (Pižl \& Starý, 2001) and urban lawns (Keplin, 1995), forest regeneration practices in France (Cancela da Fonseca, 1990), fire regime in phrygana vegetation in Greece (Sgardelis \& Margaris, 1993), oak-hickory forest in Ohio, USA (Dress \& Boerner, 2004), tropical rain forest in French Guyana (Betsch \& Cancela da Fonseca, 1995) and in Calluna-heathland soil in England (Webb, 1994). Nevertheless, microarthropods are seldom taken into consideration in management practices.

The current study is the first to examine the response of mite assemblages to fire disturbance in natural grasslands in South Africa. The aim of the study was to determine if and how oribatid mite abundance and species composition differ between a burned (treatment) and unburned (control) grassland.

\section{Materials and Methods}

\section{Study area}

The 4,000 ha Erfenis Dam Nature Reserve (including the 3,300 ha dam; 28 30 'S; $26^{\circ} 48^{\prime} \mathrm{E}$ ) is situated in the Free State Province, central South Africa. Large mammals (all natural, reintroduced antelope) and virtually the full central grassland complement of native small mammals, birds, reptiles, and small to medium sized predators are expected to reside in the reserve. The most common grasses in the reserve are Themeda triandra (red grass), Heteropogon contortus (spear grass), Aristida bipartita (rolling grass), Brachiaria eruciformis (sweet signal grass), Cymbopogon plurinodis (narrow-leaved Turpentine grass), Elionurus muticus (wire grass) as well as various herbs and shrubs.

A ca. 80 ha rectangular plot in the eastern part of the reserve was burned on 20 September 2005 according to the conservation management policy of the reserve (Lotze, 2008). For scientific purposes, a ca. 70 ha rectangular, adjacent control plot was left unburned. Neither of these plots had been burned for at least seven years prior to the September 2005 fire (R. Lotze pers. comm.). Eight months after the fire (May 2006) the average Ecological Value index (reflecting the ecological status and coverage of grasses: Vorster, 1982; Van Rooyen, 2002) in the burned area surpassed that in the control area (E. Schulze, unpub. data).

The study area was situated in a summer rainfall area with mean long-term annual rainfall of $558 \mathrm{~mm}$ (Weather Bureau, 1986) and of $762 \mathrm{~mm}$ in 2006, inside the reserve. Soil temperature was measured at $5 \mathrm{~cm}$ below ground level with a soil thermometer at the specific points where and when the soil samples were taken in 2006 (mean soil temperatures, $\mathrm{n}=18: 23 / 1=32^{\circ} \mathrm{C}, 6 / 3=30^{\circ} \mathrm{C}$, $28 / 4=15^{\circ} \mathrm{C}, 9 / 5=9^{\circ} \mathrm{C}, 1 / 9=15^{\circ} \mathrm{C}, 5 / 12=23^{\circ} \mathrm{C}$ ). 


\section{Sampling}

The first soil samples were taken four months after burning (January 2006) and continued until December 2006 for a total of six sampling events separated by one to four months. The sampling dates 23/01, 06/03, 28/04, 09/05, 01/09 and 05/12 are used as "names" for the sampling events. During each event, 9 samples were taken in the central parts (at least $150 \mathrm{~m}$ from the edges) of both the burned and control plots. A hand spade was used to get an approximately $250 \mathrm{~g}, 5 \mathrm{~cm}$ deep soil sample. These samples were taken haphazardly, but at least $20 \mathrm{~m}$ apart. Mites were extracted from samples for 48 hours using Tullgren funnels. Mites were stored in a solution of $70 \%$ alcohol and 5\% glycerol and are housed in the Acarology collection of the National Museum, Bloemfontein. Only oribatid mites were identified and used in analyses, since other mites were rarely found in the samples. Identification was done to the lowest possible taxonomic level using Balogh \& Balogh (1992) and South African literature.

\section{Analyses}

Generalized linear models (McCullagh \& Nelder, 1989) were used to determine the relation between the dependent variables (oribatid mite species richness, abundance) and explanatory variables (date sampled, burned/control). A Poisson error distribution was assumed for species richness and abundance, a logarithmic link function was used and deviance used as a measure of goodness of fit (Dobson, 2001). Statistica ${ }^{\circledR}$ (Stat Soft, Inc. 2000) was used for the analyses. A $95 \%$ level $(p<0.05)$ was regarded as statistically significant for all tests.

The mean relative abundance for each species in the burned and control plots was calculated (across all samples). Thereafter, mean relative abundance plots across sample dates were constructed for species which showed a difference of more than ten in mean relative abundance between treatments (as determined through graph analysis of the mean relative abundance plot mentioned above).

\section{Results}

A total of 2,552 oribatid mites pertaining to 49 species was collected (45 spp. in the burned plots, 39 in the control plots; see Appendix for a species list).

The date sampled contributed significantly to explain species richness and abundance (species richness: $\chi^{2}=11.16, p<0.05$, abundance: $\chi^{2}=13.84, p<0.05$ ) in burned and control plots (similarities/differences between dates within treatments are indicated by letters in Fig. 1). In general, species richness and abundance were slightly higher in the 28/4, 9/5 (autumn) and the $1 / 9$ (early spring) samples. The burned/control variable did not contribute significantly to explain mite species richness or abundance (species richness: $\chi^{2}=0.58, p=0.45$, abundance: $\chi^{2}=$ $1.77, p=0.88)$.

Mean relative abundances of soil mite species (summed across all samples per treatment) showed apparent differences between the burned and control plots (through graph analysis) (Fig. 2). The mean relative abundance of the dominant species is as follows (dominant species taken as species with mean abundance more than 20 summed across all samples): Neoliodes terrestris (Wallwork, 1963) (Burned= 37.7, Control= 25.0), Pedrocortesella parva Pletzen, 1963 (Burned= 25.0, Control= 21.7), Multioppia wilsoni Aoki, 1964 (Burned= 28.5, Control= 8.8, significantly different $p<0.05$ ), Anellozetes auriculatus (Mahunka, 1984) (Burned= 24.5, Control= 12.0), Arthrodamaeus johanni Hugo, 2010 (Burned= 20.5, Control= 15.0), Scheloribates confusia (Burned $=18.2$, Control= 4.2, significantly different $p<0.05)$, Anellozetes neonominatus (Kok, 1967) (Burned= 11.5, Control=9.0) and Tectocepheus velatus (Michael, 1880) (Burned=8.3, Control $=12.2$, significantly different $p<0.05$ ). 

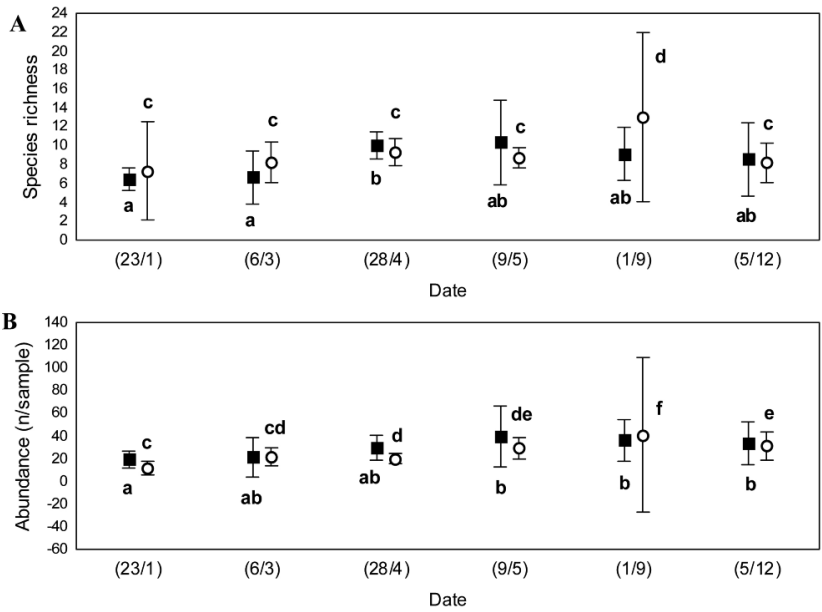

FIGURE 1. Mean ( \pm SE) soil mite species richness (A) and abundance (B), across different 2006 sampling dates in burned ( $\mathbf{\square})$ and control $(\mathrm{O})$ plots $(\mathrm{N}=9$ samples for each plot type for each date; weighted means \pm 95\% confidence intervals). Different letters indicate significant differences between dates sampled within burned and control plots, as determined by generalized linear models $(p<0.05)$; significant differences between burned and control plots on each date sampled were not observed.

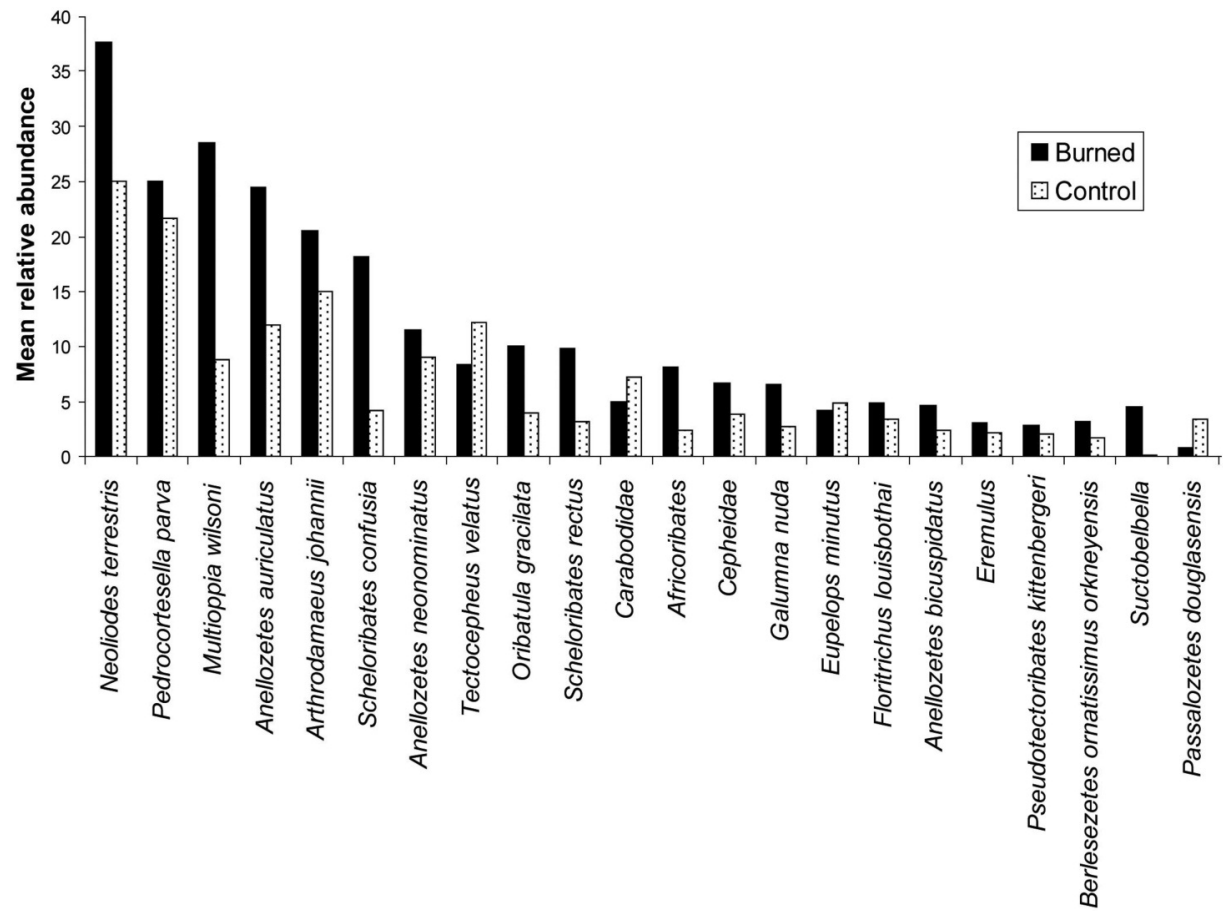

FIGURE 2. Mean relative abundances of mite species in burned and control plots. Species are ranked in order of most to least abundant; species with mean abundance less than four were not included in the graph. Erfenis Dam Nature Reserve, Free State Province, South Africa. 
Individual species abundances showed a variety of responses in the first 15 months after fire (species with a difference in mean abundance of more than ten between treatments, according to Fig. 2, are highlighted and shown in Fig. 3). Neoliodes terrestris abundance had a peak in the burned plots in month four, after which it slowly decreased. Multioppia wilsoni had a sharp increase in abundance in burned plots between months six and seven, and a sharp decrease after month 12. Anellozetes auriculatus had high abundances in the burned plots in month seven and eight. Scheloribates confusia had higher mean abundances in the burned plots (except for month 12), but without a clear peak.

\section{Discussion}

Seasonal variation in oribatid mite abundance and species richness has been confirmed by various studies and explained in terms of the reproductive cycles of mites and/or optimum conditions in terms of moisture content and temperature (Haarløv, 1960; Olivier \& Ryke, 1965; Wallwork et al., 1986). Understandably these fluctuations varied across studies. For example, mite abundance in forests in Greece was highest from middle spring to early summer (Stamou \& Sgardelis, 1989), on Sagar Island in West Bengal, mite populations peaked two times during the year, in late spring and early autumn (Sanyal \& Bhaduri, 1982) and in England moorland soils, mite abundances were highest in late spring and early winter (Block, 1966). Two studies in cultivated grasses in summer rainfall areas in South Africa showed that, in general, oribatid mite populations reached peak abun-
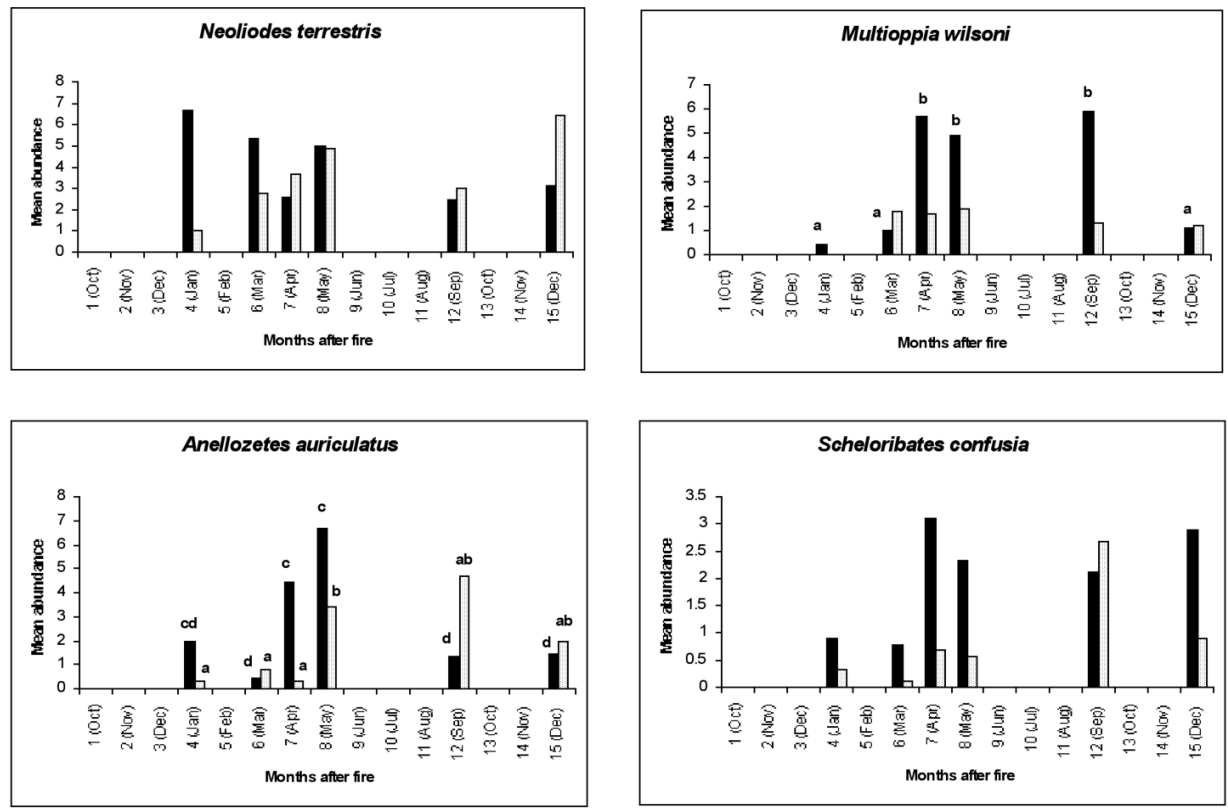

FIGURE 3. Changes in dominant mite species mean abundances in burned (solid bars) and control (dotted bars) plots. Different letters indicate significant differences between dates $(p<0.05)$ within each plot type, as determined by generalized linear models. Differences in mean abundances between burned and control plots were observed only for A. auriculatus at month 12 and S. confusia at month 6. Erfenis Dam Nature Reserve, Free State Province, South Africa. 
dances during late summer and autumn (Loots \& Ryke, 1966; Van Nieuwenhuizen et al., 1994). This is in agreement with the results of the present study, in which mite species richness and to a lesser extent abundance were the highest in middle (28/4) and late (9/5) autumn and early spring (1/9) in the control plots. Although it appears that these fluctuations are similar to that found for rodents in Free State grasslands and related to temperature and the annual build-up of vegetation (Avenant et al., 2008), our sampling protocol (not monthly or on regular intervals) preclude us from making any correlations with soil temperature or rainfall (as soil moisture was not tested).

Various things can happen to soil mites during a fire. Some mites on the surface might be killed instantly due to the heat (Madge, 1965; Malmström, 2008), while more deaths may follow soon after due to the changed microclimate. Mites with a thick cuticle may be able to withstand the heat better than others (Wikars \& Schimmel, 2001), or survive by maintaining their body temperature through evaporative cooling (Madge, 1965). They can also migrate to deeper layers in the soil (Kudryasheva \& Laskova, 2002; Moretti et al., 2006), where they are buffered through the good insulating properties of the upper layers of soil and litter (Webb, 1994; Dress \& Boerner, 2004).

The fire that occurred on September 2005 (this study) can be described as a very fast fire which spread rapidly across the landscape. The period during which a particular spot on the surface was subjected to the maximum temperature of the fire was, therefore, short, and it is expected that not all mites were killed during the fire (Webb, 1994). Indeed, Malmström (2008) found that some individuals of oribatid species such as Tectocepheus survived temperatures of up to $40^{\circ} \mathrm{C}$. When conditions in the burned area became favorable, the area was probably re-colonized by mites that survived the fire as well as mites from adjacent unburned areas (Kudryasheva \& Laskova, 2002; Moretti et al., 2006). This probably allowed the mean abundance of oribatid mites in the burned plots to reach similar levels to the mean abundance in the control plots shortly after the fire.

The majority of studies on the effect of fire on mite populations have shown lower abundances in the burned areas for a relatively long time after fire. In indigenous grassland in New Zealand, for example, mite abundance was still lower in the burned areas after three years (Barratt et al., 2006). Similar observations were made after one year in tallgrass prairie in Kansas, USA (Seastedt, 1984b), two years in phrygana vegetation in Greece (Sgardelis \& Margaris, 1993) and four years in spruce and pine boreal forests in Russia (Kudryasheva \& Laskova, 2002). However, in burned shrub vegetation in Georgia, mite species richness and densities showed recovery within four to six months after fire (Murvanidze et al., 2008). In the current study, both abundance and species richness never differed significantly between burned and control plots in the period 4-15 months after fire.

Individual species, however, showed idiosyncratic responses to fire. For instance, species like $M$. wilsoni and S. confusia were more abundant in the burned plots compared to the control plots, whereas for Tectocepheus velatus the opposite was true. These trends in abundances differed from the seasonal trends observed in the control plots and indicate that these species show potential as indicator species. Different responses of oribatid mite species to fire were also observed in various other studies. In prairie in Wisconsin, abundances of Eremobelba, Eobrachychthonius and Trichoppia increased in burned areas (Lussenhop, 1976). This was attributed to an increase in plant growth and microbial activity areas after burns. Some oribatid mite species in burned areas in shrub and forest vegetation in Georgia recovered quickly after fire (Murvanidze et al., 2008). Species such as Tectocepheus, Punctoribates punctum (Koch, 1839), Fosseremus lacinatus (Berlese, 1905) and Oppiidae species, which are ubiquitous and wide spread taxa that can tolerate extreme conditions, were the first to recover and colonize burned areas (Murvanidze et al., 2008). In several studies, T. velatus was found to be tolerant of high temperatures (Malmström, 2008) and was one of the first species to recover after fire (Webb, 1994; Murvanidze et al., 2008). This does not seem to be the case in this study (or for at least from four months onwards after the fire). In a study of burned phryganic vegetation in Greece, Scheloribates pallidulus latipes (Koch, 1844) was found to occur in higher numbers under stones than under shrubs, thus implying that the stones 
were protected microhabitats during and after fire (Sgardelis \& Margaris, 1993). Consequently, the unique responses of species such as Scheloribates, Multioppia and Tectocepheus in this and other studies reveal their potential as ideal indicator species of ecosystem restoration. Such species should be further investigated in grasslands in South Africa.

\section{Acknowledgements}

We would like to thank the management of Erfenisdam Nature Reserve for permission to carry out the fieldwork and in particular Robert Lotze of the Reserve for rainfall data and other assistance. Thanks to Louise Coetzee for taxonomic assistance. The National Museum provided the research funding as well as travel funding to attend the XIII International Congress of Acarology in Recife, Brazil. We are grateful for the insightful comments of two referees.

\section{References}

Avenant, N.L. (2005) Barn owl pellets: a useful tool for monitoring small mammal communities? Belgian Journal of Zoology, 135, 39-43.

Avenant, N.L., Watson, J.P. \& Schulze, E. (2008) Correlating small mammal community characteristics and habitat integrity in the Caledon Nature Reserve, South Africa. Mammalia, 72, 186-191.

Balogh, J. \& Balogh, P. (1992) The Oribatid mites genera of the world. Volumes 1 and 2. The Hungarian National Museum Press, Budapest, 263 pp. \& 375 pp.

Barratt, B.I.P., Tozer, P.A., Wiedemer, R.L., Ferguson, C.M. \& Johnstone, P.D. (2006) Effect of fire on microarthropods in New Zealand indigenous grassland. Rangeland Ecology and Management, 59, 383-391.

Betsch, J.M. \& Cancela da Fonseca, J.P. (1995) Changes in edaphic factors and microarthropod communities after clearing and burning in a tropical rain forest in French Guyana. Acta Zoologica Fennica, 196, 142-145.

Block, W. (1966) Seasonal fluctuations and distribution of mite populations in moorland soils, with a note on biomass. Journal of Animal Ecology, 35, 487-503.

Cancela da Fonseca, J.P. (1990) Forest management: impact on soil microarthropods and soil microorganisms Revue d'Écologie et de Biologie du Sol, 27, 269-283.

Dobson, A.J. (2001) An introduction to generalized linear models, $2^{\text {nd }}$ edition. Chapman \& Hall/CRC Text in Statistical Science, Boca Raton.

Dress, W.J. \& Boerner, E.J. (2004) Patterns of microarthropod abundance in oak-hickory forest ecosystems in relation to prescribed fire and landscape position. Pedobiologia, 48, 1-8.

Ferreira, S.M. \& Van Aarde, R.J. (2000) Maintaining diversity through intermediate disturbances: evidence from rodents colonizing rehabilitating coastal dunes. African Journal of Ecology, 38, 286-294.

Haarløv, N. (1960) Microarthropods from Danish soils: ecology, phenology. Oikos, suppl. 13, 1-176.

Keplin, B. (1995) Effects of extensive management practices on soil fauna of urban lawns. Acta Zoologica Fennica, 196, 239-242.

Krantz, G.W. \& Walter, D.E. (2009) A manual of acarology, $3^{\text {rd }}$ edition. Texas Tech University Press, Lubbock.

Kudryasheva, I.V. \& Laskova, L.M. (2002) Oribatid mites (Acariformes, Oribatei) as an index of postpyrogenous changes in podzol and peat soils of boreal forests. Biology Bulletin, 29, 92-99.

Loots, G.C. \& Ryke, P.A.J. (1966) A comparative quantitative study of the micro-arthropods on different types of pasture soil. Zoologica Africana, 2, 167-192.

Lotze, R. (2008) Integral management plan of Erfenisdam Nature Reserve. Internal Document. Department of Economic development, Tourism and Environmental Affairs.

Lubin, Y. \& Crouch, T. (2003) Trial by fire: social spider colony demographics in periodically burned grassland. African Zoology, 38, 145-151.

Lussenhop, J. (1976) Soil arthropod response to prairie burning. Ecology, 57, 88-98.

Madge, D.S. (1965) The effects of lethal temperature on oribatid mites. Acarologia, 7, 121-130.

Malmström, A. (2008) Temperature tolerance in soil microarthropods: simulation of forest-fire heating in the laboratory. Pedobiologia, 51, 419-426.

Manry, D.E. \& Knight, R.S. (1986) Lightning density and burning frequency in South African vegetation. Vegetatio, 66, 67-76. 
McCullagh, P. \& Nelder, J.A. (1989) Generalized linear models, $2^{\text {nd }}$ edition. Chapman \& Hall/CRC, Boca Raton.

Moretti, M., Duelli, P. \& Obrist, M.K. (2006) Biodiversity and resilience of arthropod communities after fire disturbance in temperate forests. Oecologia, 149, 312-327.

Mucina, L., Hoare, D.B., Lotter, M.C., du Preez, J., Rutherford, M.C., Scott-Shaw, C.R., Bredenkamp, G.J., Powrie, L.W., Scott, L., Camp, K.G.T., Cilliers, S.S., Bezuidenhout, H., Mostert, T.H., Siebert, S.J., Winter, P.J.D., Burrows, J.E., Dobson, L., Ward, R.A., Stalmans, M., Oliver, E.G.H., Siebert, F., Kobisi, K. \& Kose, L. (2006) Grassland biome. In: Mucina, L. \& Rutherford, M.C. (eds) The vegetation of South Africa, Lesotho and Swaziland. Strelitzia 19. South African National Biodiversity Institute, Pretoria, pp. $348-436$.

Murvanidze, M., Arabuli, T., Kvavadze, E.R. \& Mumladze, L. (2008) The effect of fire disturbance on oribatid mite communities. In: Bertrand, M., Kreiter, S., McCoy, K.D., Migeon, A., Navajas, M., Tixier, M.S. $\&$ Vial, L. (eds) Integrative Acarology - Proceedings of the $6^{\text {th }}$ European Congress. European Association of Acarologists, Montpellier, pp. 216-221.

Niedbala, W. (2006) Ptyctimous mites (Acari: Oribatida) of South Africa. Annales Zoologici, 56 (suppl. 1), 1-97.

Olivier, P.G. \& Ryke, P.A.J. (1965) Seasonal fluctuations of the mesofauna in soil under kikuyu grass. Memorias do instituto de investigação científica de Moçambique, 7, serie A, 235-279.

Parr, C.L., Robertson, H.G., Biggs, H.C. \& Chown, S.L. (2004) Response of African savanna ants to long-term fire regimes. Journal of Applied Ecology, 41, 630-642.

Pižl, V. \& Starý, J. (2001) The effects of mountain meadows management on soil fauna communities (on example of earthworms and oribatid mites). Silva Gabreta, 7, 87-96.

Rouget, M., Jonas, Z., Cowling, R.M., Desmet, P.G., Driver, A., Mohamed, B., Mucina, L., Rutherford, M.C. \& Powrie, L.P. (2006) Ecosystem status and protection levels of vegetation types. In: Mucina, L. \& Rutherford, M.C. (eds) The vegetation of South Africa, Lesotho and Swaziland. Strelitzia 19. South African National Biodiversity Institute, Pretoria, pp. 725-737.

Sanyal, A.K. \& Bhaduri, A.K. (1982) Seasonal changes in the density of soil oribatid mites in relation to temperature and water content of soil at Sagar Island, 24-Parganas, West Bengal. Proceedings of the Symposium on Ecological Animal Populations and Zoological Survey, Calcutta, 3, 119-126.

Seastedt, T.R. (1984a) The role of microarthropods in decomposition and mineralization processes. Annual Review of Entomology, 29, 25-46.

Seastedt, T.R. (1984b) Microarthropods of burned and unburned tallgrass prairie. Journal of the Kansas Entomological Society, 57, 468-476.

Sgardelis, S.P. \& Margaris, N.S. (1993) Effects of fire on soil microarthropods of a phryganic ecosystem. Pedobiologia, 37, 83-94.

Stamou, G.P. \& Sgardelis, S.P. (1989) Seasonal distribution patterns of oribatid mites (Acari: Cryptostigmata) in a forest ecosystem. Journal of Animal Ecology, 58, 893-904.

Statsoft, Inc. (2000) Statistica for Windows. Tulsa.

Subías, L.S. (2004) Listado sistemático, sinonímico y biogeográfico de los ácaros oribátidos (Acariformes, Oribatida) del mundo (excepto fósiles) (1758-2002). Graellsia, 60, 3-305. Available from http://www.ucm.es/info/zoo/Artropodos/Catalogo.pdf. (last viewd Jul. 2010).

Swanepoel, C.M. (1981) The effect of fire on a small mammal community. South African Journal of Zoology, $16,232-236$.

Van Nieuwenhuizen, L.C., Verster, A.J.M., Horak, I.G., Krecek, R.C. \& Grimbeek, J.R. (1994) The seasonal abundance of oribatid mites (Acari: Cryptostigmata) on an irrigated Kikuyu grass pasture. Experimental and Applied Acarology, 18, 73-86.

Van Rooyen, N. (2002) Veld management in the savannas. In: Bothma, J. du P. (ed) Game ranch management. Van Schaik Publishers, Pretoria, pp. 571-620.

Vorster, M. (1982) The development of the ecological index method for assessing veld condition in the Karoo. In: Bransby, D.I. (ed) Proceedings of the Annual Congresses of the Grassland Society of Southern Africa, $17,84-89$.

Wallwork, J.A., MacQuitty, M., Silva, S. \& Whitford, W.G. (1986) Seasonality of some Chihuahuan Desert soil oribatid mites (Acari: Cryptrostigmata). Journal of Zoology, 208, 403-416.

Weather Bureau (1986) Climate of South Africa. Climate statistics up to 1984. WB40. Government Printer, Pretoria.

Webb, N.R. (1994) Post-fire succession of cryptostigmatic mites (Acari, Cryptostigmata) in a Calluna-heathland soil. Pedobiologia, 38, 138-145.

Wikars, L.-O. \& Schimmel, J. (2001) Immediate effects of fire-severity on soil invertebrates in cut and uncut pine forests. Forest Ecology and Management, 141, 189-200.

Yeates, G.W. \& Lee, W.G. (1997) Burning in a New Zealand snow-tussock grassland: effects on vegetation and soil fauna. New Zealand Journal of Ecology, 21, 73-79. 
APPENDIX. List of species sampled and their abundances in the burned and control plots at each sampling event. Erfenis Dam Nature Reserve, Free State Province, South Africa [names after Subías, 2004 (2010) and Niedbala, 2006].

Species
Cosmochthoniidae
Cosmochthonius cf. lanatus (Michael, 1885)

\section{Epilohmanniidae}

Epilohmannia pallida Wallwork, 1962

\section{Lohmanniidae}

Cryptacarus promecus Grandjean, 1950

\section{Euphthiracaridae}

Acrotritia comteae (Mahunka, 1983)

\section{Phthiracaridae}

Atropacarus (Hoplophorella)

hamatus (Ewing, 1909)

\section{Hermanniellidae}

Hermanniella congoensis Balogh, 1958

\section{Neoliodidae}

Neoliodes terrestris (Wallwork, 1963)

\section{Licnodamaeidae}

Pedrocortesella africana Pletzen, 1963

Pedrocortesella parva Pletzen, 1963

\section{Gymnodamaeidae}

Arthrodamaeus johanni Hugo, 2010

Gymnodamaeus sp.

\section{Cepheidae}

Cepheidae sp.

\section{Microzetidae}

Berlesezetes ornatissimus orkneyensis (Engelbrecht, 1972)

\section{Astegistidae}

Furcoppia longiseta Grobler, 2003

\section{Eremulidae}

Eremulus sp.

\section{Damaeolidae}

Fosseremus laciniatus (Berlese, 1905)

\section{Eremobelbidae}

Eremobelba sp.

\section{Oppiidae}

Oppiidae sp.

Neoamerioppia africana $(\mathrm{Kok}, 1967)$

\begin{tabular}{lllllll} 
Treatment & $23 / 1$ & $6 / 3$ & $28 / 4$ & $9 / 5$ & $1 / 9$ & $5 / 12$ \\
\hline
\end{tabular}

Burned

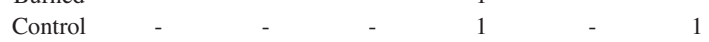

Burned

\section{Control}

Burned

Control

Burned

Control

Burned

Control

Burned

Control

Burned

Control

60

60
3

Burned

Control

Burned

Control

325

23

\section{5}

44

$\begin{array}{cc}22 & 28 \\ 9 & 58\end{array}$

$\begin{array}{ccccccc}\text { Burned } & 19 & 23 & 19 & 27 & 7 & 28 \\ \text { Control } & 1 & 37 & 6 & 20 & 4 & 22 \\ \text { Burned } & - & - & 1 & - & - & 1 \\ \text { Control } & - & - & - & - & - & - \\ & & & & & & \\ \text { Burned } & 23 & - & 3 & 2 & 2 & 10 \\ \text { Control } & 4 & 13 & - & - & 3 & 3\end{array}$

$\begin{array}{lllllll}\text { Burned } & - & 1 & 6 & 4 & 3 & 5\end{array}$

$\begin{array}{lllllll}\text { Control } & - & 2 & - & 7 & - & 1\end{array}$

Burned

Control

Burned

Control

Burned

Control

Burned

Control

Control

Burned

Control

Burned

Control 


\begin{tabular}{|c|c|c|c|c|c|c|c|}
\hline Species & Treatment & $23 / 1$ & $6 / 3$ & $28 / 4$ & $9 / 5$ & $1 / 9$ & $5 / 12$ \\
\hline \multirow[t]{2}{*}{ Lasiobelba neonominata (Kok, 1967) } & Burned & 3 & 2 & 4 & 1 & 3 & 1 \\
\hline & Control & - & 1 & - & 1 & - & - \\
\hline \multirow[t]{2}{*}{ Multioppia wilsoni Aoki, 1964} & Burned & 4 & 9 & 51 & 44 & 53 & 10 \\
\hline & Control & - & 16 & 5 & 17 & 4 & 11 \\
\hline Brachioppiella (Gressittoppia) & Burned & - & - & - & 7 & - & - \\
\hline orkneyensis $(\mathrm{Kok}, 1967)$ & Control & - & - & - & - & - & - \\
\hline \multirow[t]{2}{*}{ Kokoppia longisetosa $(\mathrm{Kok}, 1967)$} & Burned & - & - & 3 & - & 1 & - \\
\hline & Control & - & - & - & - & - & - \\
\hline \multicolumn{8}{|l|}{ Suctobelbidae } \\
\hline \multirow[t]{2}{*}{ Suctobelbella sp. } & Burned & 2 & - & 10 & 9 & 6 & - \\
\hline & Control & 1 & - & - & - & - & - \\
\hline \multicolumn{8}{|l|}{ Carabodidae } \\
\hline \multirow{2}{*}{ Austrocarabodes hendriksi Hugo, 2008} & Burned & - & - & - & 1 & - & - \\
\hline & Control & - & - & - & 2 & - & - \\
\hline \multirow[t]{2}{*}{ Carabodidae sp. } & Burned & 7 & 3 & 2 & 8 & 3 & 7 \\
\hline & Control & 5 & 1 & - & 12 & 3 & 22 \\
\hline \multicolumn{8}{|l|}{ Tectocepheidae } \\
\hline \multirow{2}{*}{ Tectocepheus velatus (Michael, 1880) } & Burned & 2 & 4 & 9 & 10 & - & 25 \\
\hline & Control & 1 & 14 & 3 & 36 & 4 & 15 \\
\hline \multicolumn{8}{|l|}{ Passalozetidae } \\
\hline \multirow[t]{2}{*}{ Passalozetes douglasensis Engelbrecht, 1974} & Burned & - & - & - & 3 & 1 & 1 \\
\hline & Control & - & 2 & - & 15 & - & 3 \\
\hline \multicolumn{8}{|l|}{ Phenopelopidae } \\
\hline \multirow[t]{2}{*}{ Eupelops minutus Grobler, 1989} & Burned & - & 1 & 2 & 17 & 4 & 1 \\
\hline & Control & 2 & 1 & 3 & 2 & 15 & 6 \\
\hline \multicolumn{8}{|l|}{ Achipteriidae } \\
\hline \multirow{2}{*}{$\begin{array}{l}\text { Pseudotectoribates kittenbergeri } \\
\text { (Balogh, 1959) }\end{array}$} & Burned & - & 2 & - & 4 & - & 11 \\
\hline & Control & - & 2 & - & 8 & - & 2 \\
\hline Humerobatidae & & & & & & & \\
\hline Africoribates sp. & Burned & - & 25 & - & 9 & - & 15 \\
\hline & Control & - & 8 & - & 5 & - & 1 \\
\hline Anellozetes sp. & Burned & - & - & - & - & - & - \\
\hline & Control & - & 1 & - & - & - & - \\
\hline Anellozetes auriculatus (Mahunka, 1984) & Burned & 18 & 4 & 40 & 60 & 12 & 13 \\
\hline & Control & 1 & 7 & 1 & 31 & 14 & 18 \\
\hline Anellozetes bicuspidatus (Mahunka, 1985) & Burned & - & 19 & 2 & - & 1 & 6 \\
\hline & Control & - & - & 1 & 11 & - & 2 \\
\hline Anellozetes neonominatus (Mahunka, 1985) & Burned & - & - & 9 & 1 & 56 & 3 \\
\hline & Control & - & 8 & - & 15 & 5 & 26 \\
\hline Zetomotrichidae & & & & & & & \\
\hline Floritrichus louisbothai Coetzee, 2003 & Burned & 3 & 3 & 11 & 2 & 8 & 2 \\
\hline & Control & - & 5 & - & 1 & 3 & 11 \\
\hline Zetomotrichus lacrimans Grandjean, 1934 & Burned & - & - & - & - & - & - \\
\hline & Control & 1 & - & 1 & - & 2 & - \\
\hline Oribatulidae & & & & & & & \\
\hline Oribatula (Zygoribatula) gracilata & Burned & - & 5 & 6 & 13 & 11 & 25 \\
\hline (Grobler \& Kok, 1993) & Control & - & 3 & 2 & 3 & 1 & 15 \\
\hline Scheloribatidae & & & & & & & \\
\hline Scheloribates sp. & Burned & - & - & 2 & 5 & - & - \\
\hline & Control & - & - & - & - & - & - \\
\hline Scheloribates confusia Coetzer, 1968 & Burned & 8 & 7 & 28 & 21 & 19 & 26 \\
\hline & Control & 1 & 1 & 2 & 5 & 8 & 8 \\
\hline Scheloribates cf. obtusus Pletzen, 1963 & Burned & - & - & - & - & - & 1 \\
\hline & Control & - & - & - & - & - & - \\
\hline Scheloribates parvus Pletzen, 1963 & Burned & - & - & - & - & 1 & - \\
\hline & Control & 1 & - & - & - & 1 & - \\
\hline Scheloribates rectus Hammer, 1958 & Burned & 7 & 2 & 6 & 6 & 5 & 33 \\
\hline & Control & 2 & 5 & 1 & 2 & 2 & 7 \\
\hline
\end{tabular}


Scheloribates cf. tricarinatus Coetzer, 1968

Haplozetidae

Afroleius simplex Mahunka, 1984

Indoribates (Haplozetes) sp.

\section{Galumnidae}

Galumna nuda Engelbrecht, 1972

Pergalumna sp.

Pergalumna elongata Engelbrecht, 1972
Burned

Control

Burned

Control

Burned

Control

\begin{tabular}{lllllll} 
Burned & 3 & 9 & - & 9 & - & 18 \\
Control & - & 5 & 3 & 3 & - & 5 \\
Burned & - & - & - & 1 & - & - \\
Control & - & - & - & - & - & - \\
Burned & 1 & - & - & 2 & - & - \\
Control & - & - & - & - & - & - \\
\hline
\end{tabular}

